University of Nebraska - Lincoln

DigitalCommons@University of Nebraska - Lincoln

USDA Forest Service / UNL Faculty Publications U.S. Department of Agriculture: Forest Service -National Agroforestry Center

April 2008

\title{
Agroforestry: working trees for sequestering carbon on agricultural lands
}

Michele M. Schoeneberger

University of Nebraska - Lincoln, mschoeneberger1@unl.edu

Follow this and additional works at: https://digitalcommons.unl.edu/usdafsfacpub

Part of the Forest Sciences Commons

Schoeneberger, Michele M., "Agroforestry: working trees for sequestering carbon on agricultural lands" (2008). USDA Forest Service / UNL Faculty Publications. 2.

https://digitalcommons.unl.edu/usdafsfacpub/2

This Article is brought to you for free and open access by the U.S. Department of Agriculture: Forest Service -National Agroforestry Center at DigitalCommons@University of Nebraska - Lincoln. It has been accepted for inclusion in USDA Forest Service / UNL Faculty Publications by an authorized administrator of DigitalCommons@University of Nebraska - Lincoln. 


\title{
Agroforestry: working trees for sequestering carbon on agricultural lands
}

\author{
M. M. Schoeneberger
}

\begin{abstract}
Agroforestry is an appealing option for sequestering carbon on agricultural lands because it can sequester significant amounts of carbon while leaving the bulk of the land in agricultural production. Simultaneously, it can help landowners and society address many other issues facing these lands, such as economic diversification, biodiversity, and water quality. Nonetheless, agroforestry remains under-recognized as a greenhouse gas mitigation option for agriculture in the US. Reasons for this include the limited informationbase and number of tools agroforestry can currently offer as compared to that produced from the decadesworth of investment in agriculture and forestry, and agroforestry's cross-cutting nature that puts it at the interface of agriculture and forestry where it is not strongly supported or promoted by either. Agroforestry research is beginning to establish the scientific foundation required for building carbon accounting and modeling tools, but more progress is needed before it is readily accepted within agricultural greenhouse gas mitigation programs and, further, incorporated into the broader scope of sustainable agricultural management. Agroforestry needs to become part of the agricultural tool box and not viewed as something separate from it. Government policies and programs driving research
\end{abstract}

M. M. Schoeneberger ( $\square)$

USDA National Agroforestry Center, Southern Research

Station, East Campus-University of Nebraska, Lincoln,

NE 68583-0822, USA

e-mail: mschoeneberger@fs.fed.us direction and investment are being formulated with or without data in order to meet pressing needs. Enhanced communication of agroforestry's carbon co-benefit, as well as the other benefits afforded by these plantings, will help elevate agroforestry awareness within these discussions. This will be especially crucial in deliberations on such broad sweeping natural resource programs as the US Farm Bill.

Keywords Biomass equations - Carbon credits . Carbon sequestration - Greenhouse gas mitigation . Woody biomass

\section{Introduction}

Despite the US's decision not to ratify the Kyoto Protocol, society is continuing to look for viable strategies to reduce atmospheric $\mathrm{CO}_{2}$, even if only as a temporary means to bank carbon until more socially and economically acceptable alternatives can be developed (USDA NRCS 2006; Williams et al. 2005). In support of this, DOE recently released the Interim General and Technical Guidelines for the 1605(b) Voluntary Greenhouse Gas Reporting Program (US DOE 2005). In these revised guidelines, Sections H (Agriculture) and I (Forestry) list activities, accounting rules and guidelines for the reporting of carbon, along with other greenhouse gas (GHG) sinks and sources that can potentially be modified by shifts in our natural resource management activities. There are 
also indications within the US of a willingness to pay for this sequestered or 'bankable' carbon. For instance, the 2002 agreement negotiated between the Pacific Northwest Direct Seed Association (PNDSA) and Entergy is for 30,000 tons of $\mathrm{CO}_{2}$ offset credits to be generated via direct seeding by PNDSA members/ growers over the next 10 years (KCARE 2003). It is still not clear what role carbon sequestration will ultimately play in US climate change strategy and markets. However, the above-listed actions suggest those natural resource practices that can provide "bankable" carbon within these governmental and private frameworks will be the ones that receive additional investment as programs are formulated.

Agroforestry intentionally combines agriculture and forestry to create integrated and sustainable land-use systems. It involves the use of working tree practices that are intentionally planted and managed in rural landscapes and communities. Additional details on these practices are available in other papers in this special edition and can also be found at the USDA National Agroforestry Center website (www.unl.edu/ nac/workingtrees.htm). These plantings represent a category of production conservation activities that can sequester large amounts of carbon while providing additional benefits to the landowner and society (Brandle et al. 1992b; Schroeder 1994; Ruark et al. 2003; Montagnini and Nair 2004; Peichl et al. 2006). The amount of carbon sequestered per unit area by agroforestry, as with most new tree plantings, is substantial due to the large amount of carbon sequestered in the woody biomass. However, unlike afforestation projects (individually large, new tree plantings), agroforestry plantings do not result in a change in land use to forest. Indeed, a lot agroforestry's appeal as a GHG mitigation activity is due to its ability to sequester large amounts of carbon on a relatively small land base ( $\sim 5 \%$ ) while leaving the bulk of the land in agricultural production (Ruark et al. 2003; USDA NAC 2000).

\section{Agroforestry-a carbon sequestering option for agricultural lands}

Attractiveness of agroforestry as a carbon sequestering activity

Of the six broad categories of agroforestry practices (Table 1), several practices, such as windbreaks and riparian forest buffers, hold especially strong promise as carbon-sequestering activities for reporting. These practices are established predominantly for ecological services other than the carbon sequestration they provide. For instance, windbreaks alter microclimate to help protect crops, livestock, buildings, and roads. Riparian forest buffers protect and enhance water quality by filtering, trapping and bioprocessing surface runoff. As these benefits accrue only if the plantings are in place and have reached a level of functional maturity, they represent a long-term commitment by the landowner. This, along with the fact that these plantings are not easily or economically converted back to prior conditions, creates a high degree of permanence for the carbon sequestered.

As mentioned earlier, agroforestry practices can give the landowner larger net gains of carbon per unit land area than many other practices (US EPA 2006). Although the carbon fixed within a single agroforestry planting is small, taken within a whole-farm context the amount can become significant (Table 2). Given the large land base in agricultural production within the US that could benefit from the non-carbon sequestering services afforded by agroforestry plantings, the potential carbon that could be sequestered by these plantings at these larger scales becomes noteworthy (see for example, Table 3 and USDA NAC 2000).

Comprising the majority of new carbon sequestered in this system (Brown 2002; Turner et al. 1995), the aboveground woody biomass of agroforestry trees is readily observed, providing a level of measurement, monitoring and verification ease (Brown 2002) not readily found in other practices where sequestration is in the soil pool (West et al. 2004). Since it represents an afforestation-like activity on agricultural lands, the baseline can be assumed to be zero or estimated using such reporting tools as the Carbon Management Evaluation Tool for Voluntary Reporting (COMET-VR) (USDA NRCS 2005). Allometric equations that relate the tree's height and diameter to its biomass allow non-destructive estimates to be made of the above and belowground woody stocks. Aerial photography, regardless of season, could be used to verify the continued presence of the practice.

By being compatible with agriculture and not converting agricultural lands to forests, use of agroforestry should not create leakage that would result in the conversion of forest land elsewhere to 
Table 1 The six categories of agroforestry practices commonly established in the US

\begin{tabular}{|c|c|c|}
\hline Practice & Description & $\mathrm{Use}^{\mathrm{a}}$ \\
\hline Riparian buffers & $\begin{array}{l}\text { A combination of trees and other vegetative types } \\
\text { established on the banks of streams, rivers, } \\
\text { wetlands and lakes }\end{array}$ & $\begin{array}{l}\text { - Reduce non-point source pollution from } \\
\text { adjacent land uses } \\
\text { - Stabilize streambanks } \\
\text { - Enhance aquatic and terrestrial habitats } \\
\text { - Economic diversification either through plant } \\
\text { production or recreational fees }\end{array}$ \\
\hline $\begin{array}{l}\text { Windbreaks (also } \\
\text { referred to as } \\
\text { shelterbelts) }\end{array}$ & $\begin{array}{l}\text { Linear plantings of trees and shrubs to form barriers } \\
\text { to reduce wind speed. Depending on the primary } \\
\text { use, the windbreak may be specifically referred to } \\
\text { as crop or field windbreak, livestock windbreak, } \\
\text { living snow fence, or farmstead windbreak }\end{array}$ & $\begin{array}{l}\text { - Control wind erosion } \\
\text { - Protect wind-sensitive crops } \\
\text { - Enhance crop yields } \\
\text { - Reduce animal stress and mortality } \\
\text { - Serve as a barrier to dust, odor and pesticide } \\
\text { drift } \\
\text { - Energy conservation } \\
\text { - Snow management to keep roads open or } \\
\text { harvest moisture }\end{array}$ \\
\hline Alley cropping & $\begin{array}{l}\text { Rows of trees planted at wide spacings while } \\
\text { growing annual crops in the alleyways }\end{array}$ & $\begin{array}{l}\text { - Diversification of crops in time and space } \\
\text { - Protect soil quality }\end{array}$ \\
\hline Silvopasture & $\begin{array}{l}\text { Trees combined with pasture and livestock } \\
\text { production }\end{array}$ & - Diversification of crops in time and space \\
\hline Forest farming & $\begin{array}{l}\text { Natural stands whose canopies have been } \\
\text { manipulated in order to grow high value crops in } \\
\text { the understory, such as mushrooms, decorative } \\
\text { florals, and medicinal herbs (i.e., ginseng) }\end{array}$ & - Diversification of crops in time and space \\
\hline $\begin{array}{l}\text { Special } \\
\text { applications }\end{array}$ & $\begin{array}{l}\text { Use of agroforestry technologies to help solve } \\
\text { special concerns, such as disposal of animal } \\
\text { wastes or filtering irrigation tailwater, while } \\
\text { producing a short- or long-rotation woody crop }\end{array}$ & $\begin{array}{l}\text { - Treatment of municipal and agricultural wastes } \\
\text { - Treatment of stormwater } \\
\text { - Center pivot corner plantings }\end{array}$ \\
\hline
\end{tabular}

\footnotetext{
${ }^{\text {a }}$ In addition to the targeted benefits listed above, agroforestry plantings can also be simultaneously managed to provide enhanced wildlife provisions for game and non-game species
}

make up for the loss of agricultural land put into agroforestry plantings. In terms of additionality, agroforestry assumes that agricultural land use will remain the landowner's primary intent and that agroforestry establishment will therefore sequester carbon over and beyond what would occur under the continuation of prior agricultural activities.

By being able to provide multiple co-benefits along with carbon sequestration, agroforestry addresses the issue of designing ecologically sound and economically appealing GHG mitigation practices. For instance, if carbon credits become tradable, biodiversity could potentially be adversely impacted through the establishment of large, even-aged monoculture plantations that can fix massive amounts of carbon but contribute little to landscape diversity. In response to a request from the United Nations Convention on Biological Diversity, this issue of climate change, mitigation strategies and biodiversity was addressed and reported in the IPCC Technical Paper-V (Gitay et al. 2002). In this report, agroforestry was identified as an activity that "can sequester carbon and have beneficial effects on biodiversity because it creates more biological diverse systems than conventional agricultural lands" (Korn et al. 2003). Conversely, large scale programs that utilize tree-based practices to address other resources, such as water quality, biodiversity and biomass feedstocks, should likewise be designed with the carbon cobenefit in mind.

Accounting for agroforestry carbon pools

For GHG mitigation efforts, it is the flux or difference in a carbon pool as affected by a shift in management practices that must be accounted for. For voluntary 
Table 2 Comparison of $\mathrm{CO}_{2}$ sequestered under two management options (all no-till and no-till with windbreaks) on a hypothetical farm $^{\mathrm{a}}$ in Saunders County, Nebraska

\begin{tabular}{|c|c|c|c|c|c|c|c|}
\hline Practice & Years & $\mathrm{Ha}$ & $\%$ Total & MT C/ha/yr & $\mathrm{MT} \mathrm{CO}_{2} / \mathrm{ha} / \mathrm{yr}$ & $\mathrm{MT} \mathrm{CO} 2$ & Total $\mathrm{MT} \mathrm{CO}_{2}$ \\
\hline \multicolumn{8}{|l|}{ Option A: no-till } \\
\hline \multirow[t]{5}{*}{ Cropland in no-till ${ }^{\mathrm{b}}$} & $1-10$ & 254 & 100 & 0.32 & 1.17 & 2,972 & 2,972 \\
\hline & $11-20$ & 254 & 100 & 0.35 & 1.28 & 3,251 & 6,223 \\
\hline & $21-30$ & 254 & 100 & 0.18 & 0.66 & 1,676 & 7,899 \\
\hline & $31-40$ & 254 & 100 & 0.09 & 0.33 & 838 & 8,737 \\
\hline & $41-50$ & 254 & 100 & 0.05 & 0.18 & 466 & 9,203 \\
\hline Option A Total & & & & & & & 9,203 \\
\hline \multicolumn{8}{|c|}{ Option B: no-till and crop windbreaks } \\
\hline \multirow[t]{5}{*}{ Cropland in no-till ${ }^{\mathrm{b}}$} & $1-10$ & 243 & 96 & 0.32 & 1.17 & 2,843 & 2,843 \\
\hline & $11-20$ & 241 & 95 & 0.35 & 1.28 & 3,085 & 5,928 \\
\hline & $21-30$ & 238 & 94 & 0.18 & 0.66 & 1,571 & 7,499 \\
\hline & $31-40$ & 238 & 94 & 0.09 & 0.33 & 785 & 8,284 \\
\hline & $41-50$ & 238 & 94 & 0.05 & 0.18 & 428 & 8,712 \\
\hline \multirow[t]{5}{*}{ Cropland in windbreaks } & $1-10$ & 11 & 4 & 0.64 & 2.36 & 260 & 260 \\
\hline & $11-20$ & 13 & 5 & 2.44 & 8.99 & 1,169 & 1,429 \\
\hline & $21-30$ & 16 & 6 & 4.69 & 17.23 & 2,757 & 4,186 \\
\hline & $31-40$ & 16 & 6 & 2.54 & 9.34 & 1,495 & 5,681 \\
\hline & $41-50$ & 16 & 6 & 2.95 & 10.84 & 1,735 & 7,416 \\
\hline Option B Total & & & & & & & 16,128 \\
\hline
\end{tabular}

Values for no-till represent $\mathrm{CO}_{2}$ sequestered in soil and were calculated using COMET for first 20 years, with subsequent 10 -year period rates being $50 \%$ of prior year's rate for total C (Brenner, J., pers. comm.). Values for cropland with windbreaks represent CO2 sequestered in above and belowground woody biomass produced by trees and were calculated using shelterbelt-derived biomass equations (Zhou 1999) and root equations presented in Cairns et al. (1997). (Adapted from Schoeneberger, M., Brandle, J., Zhou, X. and Straight, R., unpublished data)

${ }^{a}$ Hypothetical farm is 256 ha total: 2 ha farmstead, roads, ditches etc and 254 ha available for farming

b Conventional corn/soybean rotation converted to no-till operations

reporting programs or carbon markets, only those pools that can be easily, reliably and economically measured should be included (Brown 2002). Not all agroforestry practices can be easily, reliably or economically measured or even estimated for carbon sequestered at this time. Looking at Fig. 1, we can see that even in a relatively simple practice, like windbreaks, the carbon sinks and sources are many, with some being highly variable and others being difficult to separate out the different sink and/or sources of carbon (see also Sauer et al. 2007).

In Section I (Forestry) of the 1605(b) Technical Guides, where agroforestry is currently listed, the aggregated pools considered include:

- Live trees

- Understory vegetation

- Standing dead trees

- Down dead wood
- Forest floor

- Soil carbon

- Harvested wood mass in use and landfills

- Harvested wood mass burned for energy

- Harvested wood mass that results in emissions that is not used for energy.

An array of default tables developed for estimating these pools in forest stands throughout the US are contained in the Part I Appendix in the 1605(b) Report (US DOE 2005). Unfortunately, use of these default tables for estimating carbon sequestered in agroforestry plantings is questionable and needs to be investigated. The "intensive, intentional, integrated and interactive" nature of agroforestry plantings (Gold et al. 2000) results in species combinations, use of plant materials, stocking levels, management, and therefore carbon flows that are quite different than in the forest stands used for default value formulation. 
Table 3 Agroforestry potential to store carbon on Nebraska farmland

\begin{tabular}{|c|c|c|c|}
\hline \multirow[t]{2}{*}{ Agroforestry practice } & \multirow[t]{2}{*}{$\begin{array}{l}\text { Stored } \mathrm{CO}_{2} / \text { land unit }{ }^{\mathrm{a}} \text { at age } 20 \\
\text { metric tons (MT) }\end{array}$} & \multicolumn{2}{|c|}{$\begin{array}{l}\mathrm{CO}_{2} \text { storage potential for Nebraska } \\
\text { million metric tons (MMT) }\end{array}$} \\
\hline & & 20 years & 40 years \\
\hline $\begin{array}{l}\text { Field windbreak (planted on } \\
5 \% \text { of cropland) }\end{array}$ & $\begin{array}{l}\text { 36-72 MT/mile (20 ft width, } 0.4 \mathrm{mi} .=1 \mathrm{ac} .) \\
22-45 \mathrm{MT} / \mathrm{km}(6.1 \mathrm{~m} \text { width, } 0.64 \mathrm{~km})\end{array}$ & $11.7-23.4$ & $23.4-46.8$ \\
\hline $\begin{array}{l}\text { Living snow fence (high } \\
\text { priority roadways) }\end{array}$ & $\begin{array}{l}\text { 162-324 MT/mile (50 ft width) } \\
\text { 101-201 MT/km (15.2 m width) }\end{array}$ & $5.4-10.8$ & $10.8-21.6$ \\
\hline Riparian forest buffer & $\begin{array}{l}\text { 426-852 MT/mile (100 ft width, each side of stream) } \\
265-530 \mathrm{MT} / \mathrm{km} \text { ( } 30.5 \mathrm{~m} \text { width, each side of stream) }\end{array}$ & $9.2-18.4$ & $18.4-36.8$ \\
\hline Pivot irrigation corners & $\begin{array}{l}\text { 352-704 MT/pivot ( } 4 \text { corners, each } 6 \text { acres) } \\
\text { 36-72 MT/ha }\end{array}$ & & \\
\hline $\begin{array}{l}\text { Pivots below } 23 \text { inch } \\
(584 \mathrm{~mm}) \text { annual precipitation }\end{array}$ & & $6.6-13.2$ & $13.2-26.4$ \\
\hline All corner pivots & & $15.1-30.2$ & $30.2-60.4$ \\
\hline Total & & $41.4-82.8$ & $82.8-165.6$ \\
\hline
\end{tabular}

Storage values are calculated at 20 and 40 years following planting. [Developed by USDA National Agroforestry Center for the report: "Carbon Sequestration, Greenhouse Gas Emissions, and Nebraska Agriculture-Background and Potential" to the Nebraska Unicameral (NE DNR 2001)]

a Metric equivalents are shown below original values

Fig. 1 Major carbon sinks and sources in a field windbreak

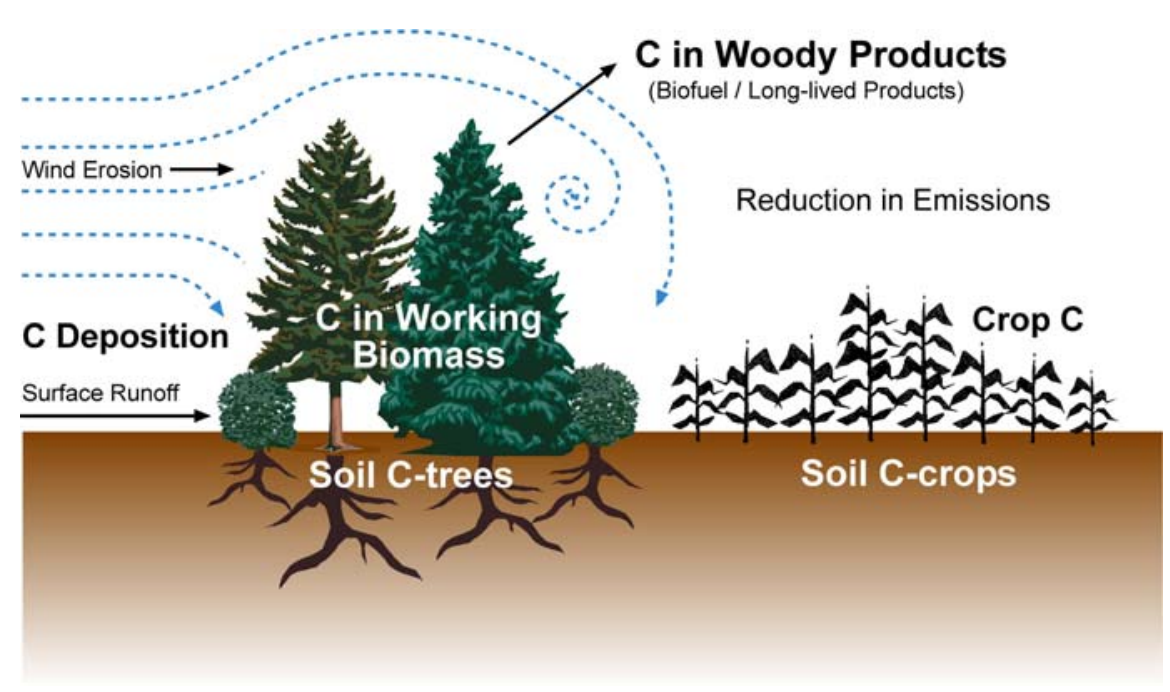

Growth and carbon allocation patterns in agroforestry trees reflect the more "open-grown" or "edgeforest" conditions created by agroforestry arrangements. The majority of woody biomass equations available for developing carbon estimates were derived from forest stands and, not unexpectedly, found to underestimate woody biomass in agroforestry plantings (Zhou 1999). Since agroforestry cannot be accurately estimated using these default tables, the difficulty in reporting increases. Therefore, in order to be appealing to landowners, voluntary reporting and carbon credit accounting will need to focus on those pools within agroforestry practices that can meet the measurement criteria of ease, reliability and economics. This would mean that the final number reported will be conservative (underestimated) but at least is one that captures the majority of carbon sequestered in these systems. The carbon pools in the context of agroforestry reporting and accounting are briefly discussed below. 
- Aboveground woody biomass: This component represents the most easily and reliably reported pool in agroforestry plantings and captures the majority of new carbon sequestered by this system (Brandle et al. 1992b; Dixon et al. 1994; Kort and Turnock 1999; Schroeder 1994).

- Belowground woody biomass: There is tremendous difficulty assessing the belowground woody biomass, even in relatively uniform conditions, such as managed loblolly pine plantations (Miller et al. 2006). This highly variable and sampling intensive/expensive pool is best estimated using available equations, such as reported by Cairns et al. (1997).

- Understory vegetation: This pool is assumed to be too small, too variable, and too labor intensive for inclusion in estimates at this time.

- Litter/forest floor/dead wood: Since most agroforestry practices involve the planting of new trees, carbon flux is this group of pools will be relatively low until trees become mature.

- Soil carbon: Most discussions regarding agricultural carbon sequestration center on the soil pool, more specifically as it is affected by different levels of conservation tillage operations [for example, see Section H in the 1605(b) Technical Guides (US DOE 2005)]. This pool and the potential levels of storage are substantial. Nonetheless, the utility of trying to estimate this pool in agroforestry systems is questionable. Looking at data from afforestation studies, such as Paul et al. (2002) and Sauer et al. (2007), we can assume that carbon sequestered in soils under agroforestry from biomass turnover will be greater than under conventional agricultural operations. However, getting a handle on what that number is will be difficult. Soil carbon in agroforestry systems is from sequestered sources (e.g., biomass turnover) and external sources deposited within the plantings [e.g., wind or surface runoff (see Fig. 1)]. The nature of both sources creates high spatial variability (Sauer et al. 2007; Sharrow and Ismail 2004) that is not easily, reliably or economically captured. So while we know carbon is sequestered in this system, measurement of this pool is best suited for purposes of research rather than reporting at this time.

Although not be covered in this paper, the additional GHG mitigation impacts afforded by agroforestry plantings beyond just sequestering carbon need to be acknowledged. The indirect benefits derived from crop and farmstead windbreaks are increased crop production, reduced wind erosion, and increased efficiency in agricultural production leading to reductions in use of fuel (which then leads directly to reduction in emissions from the combustion process), fertilizer and pesticides (Brandle et al. 1992b). Further work and tool development are needed to account for these GHG mitigation activities in addition to the direct carbon sequestration.

\section{Agroforestry: the unaccounted agricultural option in GHG mitigation programs}

If agroforestry is such an attractive carbon sequestering option for agricultural lands, why does it remain under-recognized in carbon sequestration efforts? Part of the answer rests on the very reason agroforestry works-benefits are derived from having an ecological foot in both agriculture and forestry (Olson et al. 2000). But having an ecological foot in both worlds has not translated into necessarily having a strong political foothold in either one, especially as declining research budgets have caused agencies to focus more on their more traditional and core programs.

On one hand, agroforestry is thought of as "afforestation" as it adds new trees where trees have not been before or recently. This would put it in the forestry camp. However, by definition, the size of agroforestry plantings does not qualify it as "forest land" and therefore leaves it in the agricultural camp. Perry et al. (2005) noted that agroforestry and other working tree practices were not explicitly accounted for by either of the of the two primary national natural resource inventory programs, the Forest Inventory Analysis Program of the US Forest Service and the Natural Resources Inventory of the USDA Natural Resources Conservation Service. By default, these plantings do not then get included in other reporting efforts that provide input into policy and program discussion, such as the joint agriculture and forestry GHG inventory.

In many GHG reports, agroforestry practices are absent in the lists and tables of potential mitigation activities. For example, the report on potential management practices to reduce carbon dioxide 
emissions from New Zealand agriculture did not include agroforestry within the mitigation options it listed (Clark et al. 2001). Further, it discounted the utility of grazing as a GHG mitigation strategy. The report noted that since "managing grazing land to increase carbon storage requires a larger portion of the carbon fixed in photosynthesis to be returned to the soil, that this was not an economically viable carbon sequestering option since it means reduced product output relative to inputs". Unfortunately, statements in executive summaries like these often become the take-home messages used in formulation of policies and programs. Silvopasture, where trees, pasture and livestock are combined, could prove to be highly suitable for meeting landowner needs and for GHG mitigation (Sharrow and Ismail 2004). The November 2000 World Resource Institute Climate Notes tackled the issue of Kyoto protocol intent and impact on economic well-being of farmers (Faeth and Greenhalgh 2000). Although agroforestry would have fit well within the four elements they laid out for a climate strategy for US agriculture, discussion centered on no-till agriculture with no mention of agroforestry.

The pervasiveness of no-till and the absence of agroforestry in many agriculture assessments may be a reflection of the expertise brought to the formulation tables; selectors being experts within the traditional core of each discipline-agriculture, range and forestry-and not those that crosswalk among all three. Surprisingly in the first IPCC Technical Paper entitled: "Technologies, policies and measures for mitigating climate change" (Watson et al. 1996) agroforestry was included in both the forestry and agricultural sections, a result of having used information generated by a group of scientists that included agroforestry expertise. This indicates that, when included in GHG mitigation discussions, agroforestry's potential as a carbon sequestering option seems to be recognized and suggests a more active approach to elevating the awareness of agroforestry is well warranted.

Another barrier to inclusion that may apply to agroforestry is the use of land use in categorizing GHG mitigation activities. In the case of agroforestry where it is applied versus the "home" science base creates confusion in regards to ownership and endorsement. While agroforestry is a tree-based activity thereby requiring forestry knowledge, it generally does not qualify as "forest" by definition of size (Perry et al. 2008). On the other hand, even though these tree-based practices leave the land in agricultural land use, those managing these lands for agriculture will not likely be looking to Forestry Land Use activities to glean their "agricultural" opportunities. And then there are agroforestry practices that fully integrate the tree/crop component throughout the whole farm, such as silvopasture and alleycropping, which, despite their excellent carbon sequestering/production capabilities (Nair and Nair 2003), may not be picked up by either group.

The limited amount of data and therefore scientific understanding and tools agroforestry has currently compared to the wealth of information produced from decades of investment and efforts in agronomy and forestry may also be playing a role in the limited inclusion of agroforestry in GHG programs. While practiced for many centuries, agroforestry is still a relatively new science. The impact of scientific foundation in terms of models, default tables, and tools and what activities are more readily accepted are evident in the 1605(b) Technical Guide (US DOE 2005). However, this should not exclude promising but lesser-known technologies from still being considered in the formulation of programs to address GHG mitigation.

\section{Agroforestry as part of a whole-farm GHG} accounting system

Tools that estimate carbon sequestered on the farm from several activities not only provide a more whole-farm accounting capability, but can also be instrumental in landowner consideration of other options for their land. By providing a side-by-side comparison of different combinations of activities these tools could be extremely influential in terms of endorsement, promotion and adoption of these different practices. One such example is the CarbOn Management Evaluation Tool for Voluntary Reporting (COMET VR) recently released by the USDA Natural Resources Conservation Service (USDA NRCS 2005) and included in Section $H$ of the 1605(b) technical guides (US DOE 2005). This tool provides an estimate of carbon flux in mineral soils on cultivated lands. The tool also provides data (e.g., $\mathrm{N}$-fertilizer use and fuel consumption) that can be used in reporting for other GHG sources. By 
changing management operation inputs, entities can easily compare different management scenarios. Unfortunately, this tool currently does not include agroforestry among its management options. Efforts are being initiated to investigate how tree activities on agricultural lands might be incorporated into COMET VR so that natural resource professionals and landowners can compare and report on more diversified and integrated farm management scenarios (Greg Johnson, USDA NRCS, pers. comm.).

As an exercise to see what numbers a farmer might be looking at if he or she were to put in some agroforestry practices, carbon sequestration estimates were made over a 50-year period for a hypothetical farm in Saunders County, Nebraska under two different combinations of GHG mitigations activities (see Table 2). COMET VR was used to estimate carbon sequestered in soil for the farmland under notill operations. Shelterbelt-derived biomass equations were used to estimate the carbon sequestered in the above and belowground woody biomass produced in the windbreaks (Zhou 1999). The windbreaks were designed for purposes other than carbon (i.e., to provide enhanced crop protection and production, soil protection, road protection and potentially other recreational and income opportunities through enhanced wildlife habitat) and comprised on an average $5 \%$ of the farmland during the 50-year period. Since there are many other carbon accumulating activities in windbreak systems not accounted for here (Fig. 1), the numbers presented for the windbreaks are conservative, and as discussed earlier represent the majority of the captured carbon and the most easily, reliably and economically measured and monitored. Comparing the values obtained under two scenarios indicates that Option B (no-till + windbreaks) not only might net the farmer more carbon ( $\sim 75 \%$ more in this hypothetical exercise), but also could create a more ecologically and economically sound farming strategy for the landowner and society (Brandle et al. 1992a; Kort 1988).

This inability to include agroforestry in these types of comparative exercises, from farm- to nationalscale, will contribute heavily to continued underrecognition, underutilization, and under-funding of agroforestry. A state-level example of this is the Carbon Sequestration Advisory Committee in Nebraska that was established to provide GHG recommendations to the 2000 Session of the
Nebraska Unicameral (NE DNR 2001). Typical of the problem identified in the preceding sections, original committee members were predominantly from agriculture with no forestry or agroforestry expertise represented at the table. The four major recommendations ultimately made in this report: (1) maintain a Carbon Sequestration Committee to respond to changing conditions, (2) provide additional funding for basic research relevant to Nebraska, (3) provide funding to support a carbon sequestration pilot project in Nebraska, and (4) develop a state GHG inventory again demonstrate the potential influence of those entities involved in the formulation of these reports. In this case, agroforestry and forestry expertise were later included within the Committee which is reflected in the report. In this case, despite the perception of Nebraska being a tree-less expanse of land, the potential for carbon sequestration by agroforestry practices, implemented for objectives other than carbon and on suitable lands, is large (Table 3). The development of Table 3 for other states or larger regions can serve as a simple but very powerful communication tool as we wait for more detailed scientific information to be generated.

\section{Agroforestry in future GHG mitigation strategies}

While US recognition of agroforestry as a carbon sequestering activity is lagging, there is a growing interest in other countries that have not only ratified the Kyoto Protocol but are also facing many other ecological problems on their private working lands. On November 22, 2004, the CO2 Group Limited announced its contract with Origin Energy, a leading Australian energy company, to supply carbon credit through to 2012. The agreement, considered the largest in Australia to-date and valued at up to $\$ 20$ million, is reportedly also the first carbon sink deal of its type under an emissions trading system anywhere in the world. These credits will be generated by up to 6,500 hectares of eucalyptus plantations to be established in western New South Wales as tree plantings integrated with cereal cropping agricultural systems. The plantings will be in place for more than 100 years, sequestering carbon along with providing "significant environmental benefits including mitigation of dry land salinity, enhanced biodiversity, soil conservation, water catchment protection, and 
significant employment opportunities in regional NSW" (CO2 Group Limited 2004).

Other innovative programs that target massive afforestation of marginal farmlands as one GHG tactic could also be fertile grounds for incorporating agroforestry plantings, especially where there is a need to combine carbon sequestration with landowner objectives. For example, the Emissions/Biodiversity Exchange Project (EBEX21) was initiated in 2001 by the Manaaki Whenua Landcare Research Institute as a means to "catalyze business action on energy efficiency and GHG emissions, while promoting the restoration of New Zealand's native biodiversity" (Landcare Research NZ 2005). Targeting areas, such as the one million hectares of New Zealand's marginal hill farmland, the project would help promote conversion of these lands to indigenous forest in a "process that would enable landowners to enter 'Kyoto' carbon trading markets'. This approach of shifting land use from agriculture to forests, however, may have limited acceptance and adoption by private landowners. On the other hand, strategic use of agroforestry practices within these landscapes could fix carbon, address biodiversity concerns along with soil and water issues, provide alternative income, and create a more diversified farm-forestry system that would set better with those already engaged in agricultural pursuits. As has been found with many other conservation practices, the decisionmaking process regarding adoption of carbon sequestering practices will be a complex process; not one necessarily driven by economics alone (Lynne and Kruse 2001, 2004).

The Next US Farm Bill—what role for agroforestry in carbon programs?

There are several conservation programs that currently provide financial incentives to landowners for the establishment and management of agroforestry plantings. The Farm Security and Rural Investment Act of 2002 increased financial support for many of these practices through cost-sharing, incentive, maintenance and rental payments, and producer grants (Table 4). Additional federal and state programs also support the installation and management of these practices (see USDA NAC 2003).

Beginning with the 2002 Farm Bill, there has been a growing awareness for the need to shift from commodity subsidies to more conservation and international trade (Becker 2001). Continued pressure to better align with the World Trade Organization would suggest a continued and perhaps stronger push in that direction in future Farm Bills. In the World Resources Institute report "A Climate and Environmental Strategy for US Agriculture", the authors felt that "policies could be developed that would help farm income, enhance the environment, and also reduce agricultural GHG emissions, while cutting soil erosion and nutrient pollution" (Faeth and Greenhalgh 2000). To accomplish this, one of their recommendations was to shift subsidies from farm income to support programs that would help farmers reduce environmental problems caused by agricultural activities. Once again, while the language described well what agroforestry can deliver, agroforestry was not included in the list of potential activities to address this issue.

The public's growing awareness of agroforestry and other working tree practices and the multiple services they can provide on private lands is translating into greater support in larger-scale programs, such as the Chesapeake Bay Program, Lower Mississippi Alluvial Valley, Upper Mississippi River Basin Program, and the broader Whitewater-toBluewater initiative. While these programs are focused on water quality as the primary driver, they also represent a significant opportunity to sequester additional carbon on the land. Showing policy and program makers how these plantings can help meet multiple national goals such as water quality, carbon sequestration, wildlife and income diversification is needed. This integration of multiple goals, however, raises several questions regarding whether farmers should receive support based on just a targeted service, such as water, or for a bundle of services these plantings can provide, such as water and carbon? Under a market-based environmental stewardship program, how would the carbon sequestration benefit be dealt with if the primary target and other program support are for other services? Discussions are currently on-going on what will replace the 2002 Farm Bill. This may well be a time to investigate the value of substituting commodity subsidies with tree planting subsidies (McCarl and MacCalloway 1995) that promote agroforestry. Communicating this and other potentials of agroforestry, along with the continued progress in our scientific understanding, 
Table 4 USDA programs that provide funding for working tree plantings (USDA NAC 2003 ${ }^{\mathrm{a}}$ )

\begin{tabular}{|c|c|c|c|c|c|}
\hline \multirow[t]{2}{*}{ Program } & \multicolumn{5}{|c|}{ Agroforestry practice } \\
\hline & $\begin{array}{l}\text { Alley } \\
\text { cropping }\end{array}$ & $\begin{array}{l}\text { Riparian } \\
\text { buffer }\end{array}$ & Windbreak & $\begin{array}{l}\text { Silvo- } \\
\text { pasture }\end{array}$ & $\begin{array}{l}\text { Forest } \\
\text { farming }\end{array}$ \\
\hline Conservation Reserve Program (CRP) & $\mathrm{C} / \mathrm{M} / \mathrm{R}$ & & & & \\
\hline Continuous CRP (CCRP) & & $\mathrm{C} / \mathrm{I} / \mathrm{M} / \mathrm{R}$ & $\mathrm{C} / \mathrm{I} / \mathrm{M} / \mathrm{R}$ & & \\
\hline Conservation Reserve Enhancement Program (CREP) & & $\mathrm{C} / \mathrm{I} / \mathrm{M} / \mathrm{R}$ & & & \\
\hline Environmental Quality Incentive Program (EQIP) & $\mathrm{C} / \mathrm{I}$ & $\mathrm{C} / \mathrm{I}$ & $\mathrm{C} / \mathrm{I}$ & $\mathrm{C}$ & $\mathrm{C}$ \\
\hline Wetlands Reserve Program (WRP) & & $\mathrm{C} / \mathrm{R}$ & & & \\
\hline Conservation Security Program (CSP) & $\mathrm{C} / \mathrm{R}$ & $\mathrm{C} / \mathrm{R}$ & $\mathrm{C} / \mathrm{R}$ & $\mathrm{C} / \mathrm{R}$ & \\
\hline Conservation Security Program (CSP) & $\mathrm{C} / \mathrm{R}$ & $\mathrm{C} / \mathrm{R}$ & $\mathrm{C} / \mathrm{R}$ & $\mathrm{C} / \mathrm{R}$ & \\
\hline Forest Land Enhancement Program (FLEP) & $\mathrm{C}$ & $\mathrm{C}$ & $\mathrm{C}$ & $\mathrm{C}$ & $\mathrm{C}$ \\
\hline Sustainable Agriculture Research and Education (SARE) & PG & PG & PG & PG & PG \\
\hline
\end{tabular}

C, cost share; I, incentive; M, maintenance; PG, producer grant; R, rental

a Adapted from: Godsey, L. 2002. University of Missouri, Center for Agroforestry 5-2002

will be imperative if they are to be included in future formulations of US climate change and other natural resource management strategies.

\section{References}

Becker E (2001) Administration seeks to shift farm policy from subsidies. The New York Times, 20 September 2001

Brandle JR, Johnson BB, Akeson T (1992a) Field windbreaks: are they economical? J Prod Agric 5:393-398

Brandle JR, Wardle TD, Bratton GF (1992b) Opportunities to increase tree plantings in shelterbelts and the potential impacts on carbon storage and conservation. In: Sampson RN, Hairs D (eds) Forests and global change, vol 1, chap 9. American Forests, Washington DC, pp 157-175

Brown S (2002) Measuring, monitoring, and verification of carbon benefits for forest-based projects. Phil Trans R Soc Lond (A) 360:1669-1683

Cairns M, Brown S, Helmer E, Baumgardner G (1997) Root biomass allocation in the world's upland forests. Oecologia 111:1-11

Clark H, de Klein C, Newton P (2001) Potential management practices and technologies to reduce nitrous oxide, methane and carbon dioxide emission from New Zealand agriculture. Ministry of Agriculture and Forestry, New Zealand, p 85. [On-line] Available: http://www.maf.govt.nz/mafnet/ rural-nz/sustainable-resource-use/climate/green-house-gasmigration/ghg-mitigation.pdf. Accessed 18 Apr 2005

CO2 Group Limited (2004) Group Limited announces ground breaking carbon credit sale. Media release. ANNOUNCEMENT 78. [On-line] Available: http://www. co2australia.com.au/documents/CO2ASXMediaRelease 22-11-04.pdf. Accessed 22 November 2004

Dixon RK, Winjum JK, Andrasko KJ, Lee JJ, Schroeder PE (1994) Integrated systems: assessment of promising agroforestry and alternative land use practices to enhance carbon conservation and sequestration. Clim Change 30:1-23

Faeth P, Greenhalgh S (2000) A climate and environmental strategy for U.S. agriculture. World resources climate notes, November 2000

Gitay H, Suarez A, Watson R, Dokken DJ (eds) (2002) Climate change and biodiversity - IPCC Technical Paper V. Intergovernmental panel on climate change. [On-line] Available at: http://www.ipcc.ch/pub/tpbiodiv.pdf. Accessed 5 Apr 2005

Gold MA, Rietveld WJ, Garrett HE, Fisher RF (2000) Agroforestry nomenclature, concepts and practices for the USA. In: Garrett HE et al (eds) North American agroforestry: an integrated science and practice. American Society of Agronomy, Inc., Madison, WI, USA, pp 63-77

KCARE Environmental News (2003) Soil carbon and climate change news. \# 26. October 31, 2003. [On-line] Available at: http://www.oznet.ksu.edu/ctec/newsletter/10_31_03. htm. Accessed 10 Apr 2005

Korn H, Ntayombya P, Berghall O, Cotter J, Lamb R, Ruark G, Thompson I (2003) Climate change mitigation and adaptation options: links to, and impacts on biodiversity, chap 4, pp 48-87. In: Secretariat of the convention on biological diversity (2003) Interlinkages between biological diversity and climate change. Advice on the integration of biodiversity considerations into the implementation of the United Nations Framework Convention on Climate Change and its Kyoto protocol. Montreal, SCDB, p 154 (CBD Technical Series no. 10). [On-line] Available at http://www.biodiv.org/doc/publications/ cbd-ts-10.pdf. Accessed 19 Apr. 2006

Kort J (1988) Benefits of windbreaks to field and forage crops. Agric Ecosyst Environ 22/23:165-190

Kort J, Turnock R (1999) Carbon reservoir and biomass in Canadian prairie shelterbelts. Agrofor Syst 44:175-186

Landcare Research New Zealand (2005) EBEX21 Project. [Online] Available: http://www.ebex21.co.nz/html/WhatIs Ebex21.aspx?Flash=false. Accessed 25 Apr 2005 
Lynne G, Kruse C (2001) Conceptual framework for greenhouse gas sequestration alternatives. Report to: University of Nebraska Public Policy Center, University of Nebraska-Lincoln. [On-line] Available: http://ppc.unl. edu/publications/documents/carbonsequest_conceptualfra mework.pdf. Accessed 9 Feb 2006

Lynne G, Kruse C (2004) Farmer views on the emerging carbon market. (14 January 2004) Cornhusker Economics, Cooperative Extension, Inst. of Agriculture \& Natural Resources, University of Nebraska - Lincoln. [On-line] Available: http://agecon.unl.edu/pub/cornhusker/1-14-04. pdf. Accessed 9 Feb 2006

McCarl B, MacCallaway J (1995) Carbon sequestration through tree planting on agricultural lands. In: Lal R et al (eds) Soil management and greenhouse effect. Advances in soil science, chap. 27. CRC, Lewis Publishers, Boca Raton, LA, pp 329-338

Miller AT, Allen HL, Maier C (2006) Quantifying the coarseroot biomass of intensively managed loblolly pine plantations. Can J For Res 36:12-22

Montagnini F, Nair PKR (2004) Carbon sequestration: an underexploited environmental benefit of agroforestry systems. In: Nair PKR, Rao MR, Buck LE (eds) New vistas in agroforestry: a compendium for the 1st world congress of agroforestry, 2004. Kluwer Academic Publishers, Dordrecht, The Netherlands, pp 281-295

Nair PKR, Nair VD (2003) Carbon storage in North American agroforestry systems. In: Kimble J, Heath LS, Birdsey RA, Lal R (eds) The potential of U.S. forest soils to sequester carbon and mitigate the greenhouse effect. CRC Press, Boca Raton, FL, pp 333-346

Nebraska Department of Natural Resources (2001) Carbon sequestration, carbon emissions, and Nebraska - background and potential. A report relating the requirements of LB 957 of the 2000 Session of the Nebraska Unicameral and containing the recommendations of the Carbon Sequestration Advisory Committee, December 1, 2001

Olson R, Schoeneberger M, Aschmann S (2000) An ecological foundation for temperate agroforestry. In: Garrett $\mathrm{HE}$ et al (eds) North American agroforestry: an integrated science and practice. ASA Special Publication, Madison, WI, pp 31-61

Paul KI, Polglase PJ, Nyakuengama JG, Khanna PK (2002) Change in soil carbon following afforestation. For Ecol Manage 168:241-257

Peichl M, Thevathasan NV, Gordon AM, Huss J, Abohassan RA (2006) Carbon sequestration potentials in temperate tree-based intercropping systems, southern Ontario, Canada. Agroforest Syst 66:243-257

Perry CH, Woodall CW, Schoeneberger MM (2005) Inventorying trees in agricultural landscapes: towards an accounting of working trees. In: Proc 9th N Am Agroforest Conf. Rochester MN, 12-15 June 2005 [CD-ROM]. Dept Forest Resources, Univ Minnesota, St. Paul, MN, p 5

Perry CH, Woodall CR, Liknes GC, Schoeneberger MM (2008) Fillings the gap: improving estimates of tree resources in agricultural landscapes. Agroforestry Systems. doi:10-1007/s10457-008-9125-6

Ruark G, Schoeneberger M, Nair PK (2003) Agroforestry helping to achieve sustainable forest management. In: The role of planted forests in sustainable forest management: reports and papers of the UNFF Intersessional Experts Meeting, 25-27 March 2003, Wellington, NZ, pp 240-253 (ISBN-0478-07758-0). [On-line] Available: http://www. maf.govt.nz/mafnet/unff-planted-forestry-meeting/conferencepapers/roles-for-agroforestry.htm. Accessed 5 Apr 2005

Sauer TJ, Cambardella CA, Brandle JR (2007) Soil carbon and tree litter dynamics in a red cedar-scotch pine shelterbelt. Agroforest Syst 71:163-174

Schroeder P (1994) Carbon storage benefits of agroforestry systems. Agroforest Syst 27:89-97

Sharrow SH, Ismail S (2004) Carbon and nitrogen stores in agroforests, tree plantations, and pastures in western Oregon, USA. Agroforest Syst 60:123-130

Turner DP, Koerper GJ, Harmon M, Lee JJ (1995) A carbon budget for forests of the conterminous United States. Ecol Appl 5:421-436

USDA National Agroforestry Center (2000) Working trees for carbon: windbreaks in the U.S. USDA Forest Service and USDA Natural Resources Conservation Service, Lincoln, NE. [Online] Available: http://www.unl.edu/nac/brochures/ wbcarbon/wbcarbon.pdf. Accessed 15 Apr 2005

USDA National Agroforestry Center (2003) Incentives for agroforestry: 2002 Farm Bill. Inside Agroforestry. [Online] Available: www.unl.edu/nac/ia/winter03/winter03.pdf. Accessed 20 Apr 2005

USDA Natural Resources Conservation Service (2005) COMET VR - CarbOn Management evaluation Tool for Voluntary reporting. USDA Natural Resources Conservation Service. [On-line] Available: http://www.cometvr. colostate.edu/. Accessed 27 Apr 2005

USDA Natural Resources Conservation Service (2006) Opportunities for managing carbon sequestration and greenhouse gas emissions in agricultural systems. USDA Natural Resources Conservation Service. [On-line] Available: http://www.nrcs.usda.gov/feature/outlook/ Carbon.pdf. Accessed 8 May 2006

US Department of Energy (2005) Draft technical guidelines. Voluntary reporting of greenhouse gases 1605(b) program. March 2005. [On-line] Available: http://www.pi/ energy.gov/pdf/library/DraftTechnicalGuideliensMar21. pdf. Accessed 22 April 2005

US Environmental Protection Agency (2006) Representative carbon sequestration rates and saturation periods for key Agricultural \& forestry practices. March 2006. [On-line] Available: http://www.epa.gov/sequestration/rates.html. Accessed 9 September 2006

Watson RT, Zinyowera MC, Moss RH (1996) Technologies, policies and measures for mitigating climate change IPCC Technical Paper I. Intergovernmental Panel on Climate Change. [On-line] Available: http://www.gcrio. org/ipcc/techrepI/index.html. Accessed 5 Apr 2005

West TO, Marland G, King AW, Post WM (2004) Carbon management response curve: estimates of temporal soil carbon dynamics. Environ Manage 33:507-518

Williams JR, Peterson JM, Mooney S (2005) The value of carbon credits: is there a final answer. J Soil Water Conserv 60:36A-40A

Zhou X (1999) On the three-dimensional aerodynamic structure of shelterbelts. PhD. Dissertation, University of Nebraska, Lincoln, NE 